\title{
PENGARUH COVID-19 TERHADAP HUKUM LINGKUNGAN DI INDONESIA DITINJAU DARI ASPEK PERILAKU SOSIAL
}

\author{
Riska, Aminah \\ Mahasiswa MIH Fakultas Hukum Universitas Diponegoro \\ Dosen Fakultas Hukum Universitas Diponegoro \\ riska.rafi07@gmail.com,aminahlana@gmail.Com
}

\begin{abstract}
Abstrak
Corona virus disease 2019 (covid-19) muncul pertama kali sejak akhir 2019 di wuhan, china. Menyebar ke Indonesia sekitar februari 2020.sampai sekarang angka kasusnya semakin meningkat. berbagai dampak yang ditibulkan, baik dampak positif maupun negatif. pengaruh tersebut cukup signifikan di dalam masyarakat, bahkan Indonesia telah memasuki era new normal sejak awal juni lalu. Meski demikian, masyarakat tetap diharuskan beraktivitas sesuai dengan protokol kesehatan, terutama perilaku physical distancing dan pola hidup yang sehat. Harus disadari bahwa segala sesuatu yang terjadi pada lingkungan, tidak terlepas dari campur tangan manusia, sehingga dampaknya juga kembali kepada manusia itu sendiri. Perilaku masyarakat dalam memerangi covid-19, mendorong sikap manusia untuk saling membutuhkan satu sama lain, hal tersebut merupakan proses simbiosis mutualisme sebagai konsekuensi logis yang harus dihadapi masyarakat. Tulisan ini menggunakan metode penelitian kualitatif, dengan pendekatan yuridis normatif untuk mendeskripsikan permasalahan dampak covid-19 terhadap lingkungan hidup, serta pengaruhnya terhadap perilaku sosial. Dengan tujuan untuk memahami perilaku sosial dalam lingkungan hidup ditengah pandemi covid-19.
\end{abstract}

\section{Kata Kunci ; Covid-19, Lingkungan Hidup, Perilaku Sosial}

\section{Corona virus disease 2019 (covid-19) first appeared since the end of 2019 in} Wuhan, China. Spread to Indonesia around February 2020.Various impacts that were generated, both positive and negative impacts. As well as significant influence in society, even Indonesia has entered a new normal era since early June, but people are still required to behave in accordance with health protocols, especially physical distancing behavior and healthy lifestyles. It must be realized that everything that happens to the environment, it can not be separated from human intervention, so that the impact also returns to humans themselves. Community behavior in combating covid-19, encouraging human attitudes to need one another, this is a process of symbiotic mutualism as a logical consequence that must be faced by society. This paper uses qualitative research methods, with a normative juridical approach to describe the problem of covid-19 impact on the environment and its influence on social behavior. With the aim of understanding social behavior in the environment amid the covid-19 pandemic.

\section{Keywords: Covid-19, Environment, Social Behavior}

\section{A. Latar Belakang}

Pada awal 2020, dunia diperhadapkan dengan wabah covid-19 yang bermula di wuhan, awalnya penyakit ini dinamakan sebagai 2019 novel coronavirus (2019- $n C o V)$.Seiring perkembangan, badan kesehatan dunia (WHO) telah mengganti nama baru pada 11 februari 2020 yaitu corona virus disease (covid-19), dan ditetapkan sebagai pandemi yang diumumkan pada 12 
maret 2020 oleh WHO. ${ }^{1}$ Covid-19 ini telah melanda sebagian besar Negara di dunia, yang memberikan dampak terhadap lingkungan. Baik dari segi ekonomi, sosial maupun lingkungan hidup. Pandemi ini berhasil mengubah pola hidup sosial masyarakat, didasarkan pada kebijakan pemerintah yang menganjurkan masyarakatsaling membatasi diri dalam berinteraksi satu sama lain secara langsung. Dewasa ini, covid19 secara perlahan telah mengubah kondisi lingkungan hidup, yang memiliki dampak negatifmaupun dampak positif terhadap alam dan lingkungan sosial.

Penelitian ini dapat menggambarkan pergeseran pola pikir dan perilaku masyarakat dalam menghadapai covid-19. Covid-19 merupakan jenis virus yang menular dari manusia ke manusia, maka dari itu pemerintah mengeluarkan kebijakan Peraturan Pemerintah Nomor 21 Tahun 2020 Tentang Pembatasan Sosial Berskala Besar (PSBB). Kemudian dilanjutkan dengan Peraturan Menteri Kesehatan Nomor 9 Tahun 2020 Tentang Pedoman Pembatasan Sosial Berskala Besar dalam rangka percepatan penanganan covid-19pada daerah yang terdampak.

Pada dasarnya, awal mula munculnya covid-19 berasal dari campur tangan manusia, terlepas dari perdebatan antara senjata biologis yang sengaja diciptakan atau murni berasal dari hewan hingga menyebar ke manusia. Sebagaimana kita ketahui, bahwa segala sesuatu terjadi yang dapat mengubah lingkungan atau terjadinya kerusakan terhadap lingkungan, itu tidak terlepas dari ulah manusia. perilaku manusia dalam pencemaran lingkungan, dari perilaku tersebut dapat memunculkan virus seperti; HIV AIDS, SARS, hingga covid-19 yang kini sedang melanda Indonesia dan dunia. Siklus itu akan terus berputar jika kesadaran manusia masih mengabaikan lingkungan.

\footnotetext{
${ }^{1}$ Adityo Susilo, Dkk, “Coronavirus Disease 2019: Tinjauan LiteraturTerkini”. Jurnal Penyakit Dalam Indonesia7 No. 1 (2020). Hlm. 45
}

Sejak covid-19 melanda Indonesia, restoran, warung makan dan lain sebagainya hampir semua menggunakan bahan sekali pakai yang menghasilkan sampah plastik. Alat pelindung diri (APD) sekali pakai juga semakin meningkat, bukan hanya tim medis,tetapi mayoritas masyarakat turut menggunakan demi keselamatan dan kesehaatan.Oleh karena itu, manusia harus sadar akan moral dan tanggung jawab terhadap lingkungan hidup agar tidak terjadi krisis ekologi. Melalui teori deep ecology, menuntut etika baru yang tidak hanya berpusat pada manusia melainkan berpusat pada keseluruhan kehidupan lingkungan dengan berusaha mengatasi persoalan lingkungan hidup. ${ }^{2}$

Covid-19 ini bukan hanya menimbulkan kerusakan lingkungan, akan tetapi ditinjau dari aspek kehidupan sosial, sangat nyata perputaran ekonomi melemah, sektor industri tidak berjalan normal, sistem pemerintahan melambat, sistem pendidikan menimbulkan banyak masalah. Hal ini dapat menghambatsistem pembangunan di Indonesia berdasarkan prinsip pembangunan berkelanjutan (sustainable depelompment). Meskipun pemerintah Indonesia telah mempersiapkan konsep new normal di tengah pandemi dengan tujuan pemulihan ekonomi nasional, tetapi pola hidup tetap berpedoman dengan kebijakan-kebijakan pemerintah yaitu sesuai dengan protokol kesehatan.

Dalam waktu dekat, Indonesia belum bisa normal seperti sedia kala, karena melihat angka kasus covid-19 terus meningkat setiap hari. Rata-rata penigkatan kasus datang dari kota-kota besar, seperti DKI Jakrta, Sulawesi selatan, dan jawa tengah. Semakin hari semakin menunjukkan kurva penyebaran covid-19 indonesia semakin meningkat. Bahkan penanganan tidak sebanding dengan penambahan angka kasus, meskipun pemerintah telah berupaya de-

\footnotetext{
${ }^{2}$ Antonius Atosokhi Gea, And Antonina Panca Yuni Wulandari, Relasi Dengan Dunia. (Jakarta: PT Elex Media Komputindo 2013). Hlm. 58-59
} 
ngan penyediaan tenaga medis, sarana prasarana dan anggaran. Latar belakang ini, menggambarkan dampak yang telah ditimbulkan dan akan dihadapi Indonesia di tengah pandemi covid-19 dengan tujuan untuk menyadarkan masyarakat tentang etika dan moral dalam berperilaku terhadap lingkungan, serta mengarahkan pola pikir dan perilaku yang lebih disiplin selama pandemi.

\section{B. Rumusan Masalah}

Berdasarkan latar belakang masalah yang telah diurai di atas, maka permasalahan yang paling mendasar dalam penelitian ini, yaitu bagaimanadampak covid-19 terhadap lingkungan serta pengaruhnya terhadap perilaku sosoal?.

\section{Tujuan Penelitian}

Penelitian ini dilakukan dengan tujuan untukmenganalisis dan menguraikan tentang dampak covid-19 terhadap lingkungan serta pengaruhnya terhadap perilaku sosial.

\section{Metode Penelitian}

Metode penelitian yang digunakan dalam penulisan ini menurut analisisnya adalah penelitian kualitatif. Penelitian kualitatif merupakan suatu penelitian yang ditujukan untuk mendeskripsikan dan menganalisis peristiwa, fenomena, aktivitas sosial, sikap, kepercayaan, persepsi, pemikiran orang secara individual maupun kelompok. ${ }^{3}$ Penelitian kualitatif ini didukung oleh bahan-bahan penelitianyang menggunakan bahan hukum sekunder yang dilakukan dengan studi pustaka terhadap bahan-bahan hukum yang berupaPeraturan PerundangUndangan dan bahan-bahan non hukum. Bahan-bahan non hukum yang dimaksud adalah berupa buku-buku, jurnal, laporan hasil penelitian mengenai ilmu ekonomi, politik dan disiplin ilmu lainnya. ${ }^{4}$ Bahanbahan non hukum ini diterapkan dalam

\footnotetext{
${ }^{3}$ Sukmandinata, N.S Dalam Suteki AndGalang Taufani, Metodologi Penelitian Hukum (Filsafat, Teori Dan Praktik), (Depok: Rajawali Pers, 2018). hlm. 193

${ }^{4}$ Zinuddn Ali, Metode Penelitian Hukum(Jakarta: Sinar Grafika2016). hlm. 57
}

menganalisis permasalahan yang diangkat sesuai dengan bidang ilmu hukum lingkungan, ilmu sosial, dan disiplin ilmu lainnya.

\section{E. Hasil dan Pembahasan}

\section{Dampak Covid-19 Terhadap Hukum Lingkungan Di Indonesia}

Tujuan lingkungan hidup berdasarkan Undang-Undang Nomor 32 Tahun 2009 tentang pengelolaan dan perlindungan lingkungan hidup, secara garis besar, yaitu untuk melindungi wilayah Indonesia dari pencemaran lingkungan, menjamin keselamatan, kesehatan, dan kehidupan manusia. Pencemaran lingkungan dimaksud adalah dapat berupa dampak buruk terhadap manusia. Maka dalam tataran regulasi, keselamatan dan kesehatan kehidupan manusia sangat penting, terutama dalam memerangi penyebaran covid-19.

Di sisi lain, Undang-Undang Nomor 32 Tahun 2009 tentang pengelolaan dan perlindungan lingkungan hidup, dalam kajian penulis terkait dampak covid-19, bukan hanya memikirkan keselamatan manusia, tetapi juga memperhatikan daya dukung lingkungan hidup. Artinya tetap berharap keseimbangan antara perikehidupan manusia dan makhluk hidup lainnya. Karena dalam melestarikan lingkungan hidup bukan hanya untuk memenuhi kebutuhan manusia tetapi juga untuk alam semesta. Kedua komponen tersebut saling membutuhkan satu sama lain, yaitu alam untuk manusia, dan manusia untuk alam. Maka merugilah manusia yang selalu acuh dan merasa tidak memiliki tanggung jawab terhadap lingkungan alam, terutama dilingkungan sekitar.

Pengaruh covid-19 terhadap lingkungan sosial, mengharuskan tim medis dan seluruh masyarakat yang terdampak untuk merubah pola hidup dan perilaku sosial. Terutama menjaga jarak fisik serta mengubah kebiasaan-kebiasaan lama. Kini masyarakat harus mengonsumsi bahan yang sifatnya sekali pakai, seperti masker, handscoon (sarung tangan), dan alat pelindung diri (APD) lainnya, serta plastik makanan dan minuman sekali pakai. Hal itu dapat meng- 
hasilkan sampah yang berpotensi menimbulkan pencemaran terhadap lingkungan hidup. Itu merupakan sebagian dari pada dampak yang ditimbulkan. Dampak covid 19 dapat dikaji dari sisi negatif dan positifnya yaitu;

\section{1) Dampak Positif}

Pertama, dikaji dari sisi po-sitif dampak covid-19 terhadap lingkungan, dengan melihat perkembangan lingkungan sosial, banyak industri, jaringan transportasi dan perusahaan, kampus, dan sekolah tutup dan kegiatan kebanyakan dirumahkan. Maka tingkat emisi karbon di udara turun drastis. Karena kativitas kendaraan berkurang pula selama pembatasan sosial, sehingga polusi yang dihasilkan juga menurun. Pembatasan sosial ini diterapkan oleh pemerintah demi mencegah penyebaran covid-19, juga memberkan dampak terhadap kualitas udara. Karean setiap orang berhak atas udara yang sehat dan segar, juga demi memperbaiki kesehatan dan kulaitas hidup setiap orang.

Kebijakan pemerintah seba-gian Negara yang menerapkan lock-down dan menerapkan kebijakan PSBB membuat aktivitas berkurang di luar rumah. Sehingga berdampak positif terhadap emisi di udara. Seperti di China tingkat emisi di awal tahun berkurang 25 persen, Setidaknya transportasi menyumbang 23 persen dari total emisi karbon global, penurunan emisi di Negara-negara ini terjadi karena kebijakan membatasi aktivitas warga. Sehingga transportasi darat dan udara penyumbang utama terhadap berkurangnya emisi sebanyak 72 persen dan 11 persen lainnya dari gas rumah kaca. ${ }^{5}$ Pengurangan emisi tersebut dapat memberikan kualitas

\footnotetext{
${ }^{5}$ Martha Henriques, "Virus Corona: Dampak 'Lockdown' Pada Penurunan Polusi, Akankah Selamanya?, 2020, Https://Www.Bbc.Com/Indonesia/Vert-Fut52194438. Akses 4 Juni 2020.
}

udara yang segar, terutama dirasakan pada malam hari. Menurut pengamatan penulis, akhir-akhir ini udara sejuk bisa dirasakan pada saat larut malam sampai pagi hari.

Penyebaran covid-19 ini bukan semata-mata dipandang sebagai mala petaka untuk masyarakat, tetapi disamping banyaknya korban jiwa selama pandemi, juga memiliki sisi positif terhadap lingkungan. Meskipun masyarakat lebih banyak merasakan dampak negatifnya dalam keberlangsungan hidup seharihari. Tetapi dampak positifnya juga dapat dirasakan meskipun tidak seberapa, setidaknya berfungsi untuk kelestarian lingkungan di udara maupun di laut. Yang dapat juga dirasakan oleh manusia.

Pengaruh tersebut merupakan hasil dari pergeseran perilaku manusia dalam kehidupan sosial. Kebiasaan mayoritas masyarakat yang beraktivitas di luar semakin berkurang sehingga volusi dari kendaraan semakin berkurang secara global. Di Indonesia, mengalami perubahan iklim selama aktifitas masyarakat beralih ke work from home (WFH)atau kerja dari rumah, yaitu memberikan dampak positif terhadap kualitas udara.

Khususnya di Jakarta yang dikenal kota yang sangat padat penduduk dan aktivitas transportasi yang padat pula, secara otomatis polusi yang diharilkan setiap hari juga semakin meningkat. sehinggahal tersebut kualitas udara tercemar secara terus menerus. Tetapi sejak dikeluarkan kebijakan WFH untuk pekerja dan pelajar, berdasarkan pemantauan oleh dinas lingkungan hidup DKI Jakarta di lima stasiun menunjukkan bahwa perbaikan kualitas udara semakin meningkat, terutama menurunnya konsentrasi parameter PM 2,5 selama 
penerapan WFH. ${ }^{6}$ Sebagaimana kita ketahui bahwa kota Jakarta merupakan penyumbang terbesar polusi berdasarkan penelitian, knalpot mobil dan motor secara normal dapat menyumbang 19.350 ton polutan per hari, yang diperkirakan sekitar 47 persen dari total emisi di Jakarta. Dengan adanya covid-19 yang melanda, kebijakan pembatasan sosial memberikan dampak terhadap lingkungan, yaitu penigkatan kualitas udara.

2) Dampak Negatif

Kedua, dampak negatif terhadap kondisi lingkungan akibat covid19 merupakan dampak yang sangat nyata dirasakan oleh masyarakat, Antara lain. Pertama, angka kasus covid19 semakin meningkat setiap hari. Secara global, Indonesia cukup signifykan penambahan kasus di setiap wilayah terutama di kota-kota besar, yang memiliki penduduk yang padat. Kedua, angka kematian juga cukup meningkat selama pandemi, setiap penambahan kasus turut disertai dengan korban jiwa. Meskipun tidak sebanding dengan penambahan kasus dan korban jiwa, tetapi masyarakat tetap harus waspada.setiap orang yang teridentifikasi mengidap covid-19, semua akan dirawat oleh tim medis, tanpa bertemu dengan keluarga sampai sehat. Bahkan yang meninggal dunia pun tidak lagi menjadi tanggung jawab keluarga untuk mengebumikan, melainkan menjadi tanggung jawab tim medis atau pihak rumah sakit. Tentu hal ini sudah menjadi lazim ditelinga kita, terutama yang memiliki riwayat covid-19.

${ }^{6}$ Ayu Isti Prabandari, Pandemi Covid-19 Kurang Polusi Udara Sejumlah Negara, Begini Di Indonesia, 2020 , Https://Www.Merdeka.Com/Jateng/Pandemi-Covid19-Kurangi-Polusi-Udara-Sejumlah-Negera-IniFakta-Yang-Terjadi-Di-Indo-Kln.Html. Akses 6 Juni 2020.
Seperti pada tabel di bawah ini dapat kita bandingkan angka kasus pada setiap Negara di bawah ini, menunjukkan Indonesia berada pada posisi ke tiga tertinggi angka kasus diantara Negara-negara se Asia. Terkonfirmasi melalui data yang diperoleh dari organisasi kesehatan dunia (WHO).

Tabel 1. WHO supports countries to mitigate COVID-19 spread in the Region ${ }^{7}$

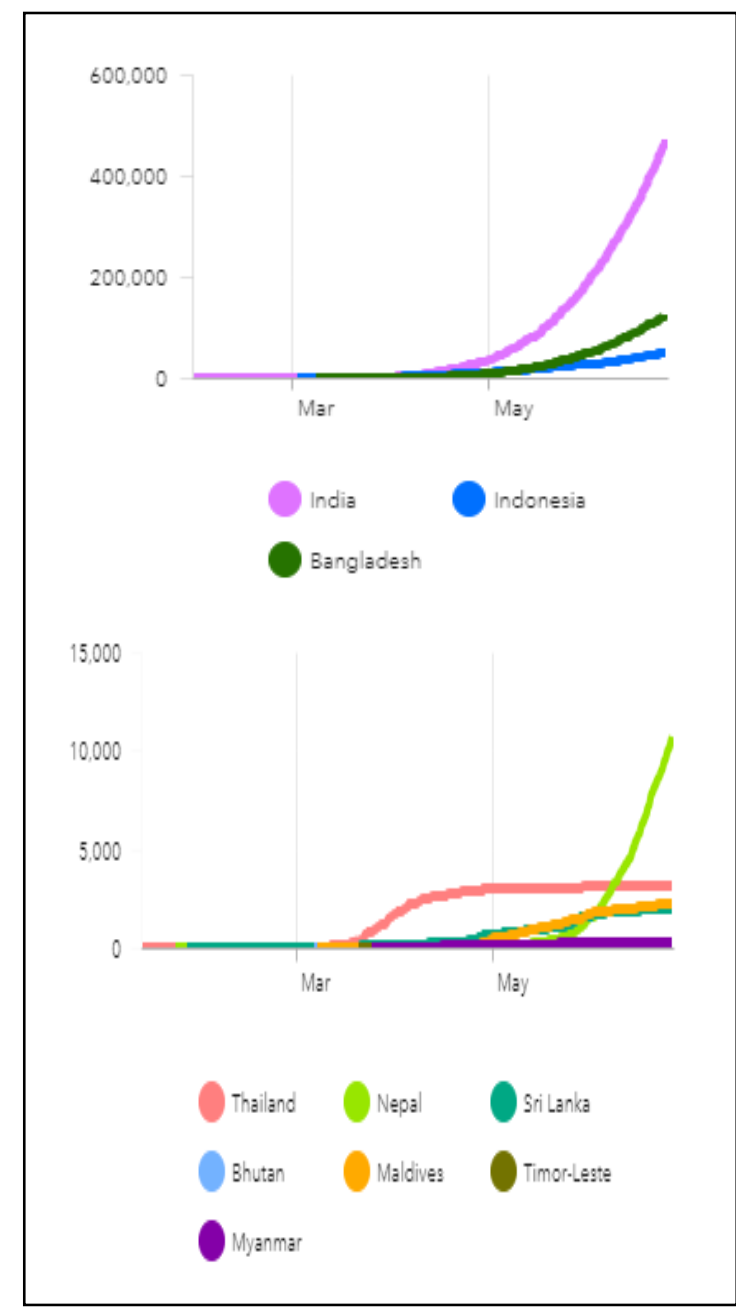

Sumber: Word Health Organization (WHO)

Kurva penyebaran covid-19 dapat dilihat bahwa indonesia berada

${ }^{7}$ World Health Organization South-East Asia, Who Supports Countries To Mitigate Covid-19 Spread In The Region, 2020 Https://Www.Who.Int/Southeastasia/Outbreaks -And-Emergencies/Novel-Coronavirus-2019. Akses 26 Juni 2020. 
pada titik warna biru yang menunjukkan, pada awal 26 juni 2020 terkonfirmasi 50.187 kasus dan angka kematian sebanyak 2.620 jiwa. Penambahan kasus di Indonesia cukup signifikan setiap hari. Covid-19 ini merupakan bencana nasional ke tiga yang melanda indonesia yang parah dan penangannya cukup menguras tenaga dan anggaran.

Tabel 2. WHO supports countries to mitigate COVID-19 spread in the Region ${ }^{8}$

\begin{tabular}{|c|c|}
\hline $\begin{array}{l}\text { SEAR total cases } \\
668,875\end{array}$ & $\begin{array}{l}\text { Total deaths } \\
19,244\end{array}$ \\
\hline \multicolumn{2}{|c|}{$\begin{array}{l}\text { Country - Confirmed cases } \\
\text { (deaths) }\end{array}$} \\
\hline \multicolumn{2}{|c|}{ India - 473,105 (14,894) } \\
\hline \multicolumn{2}{|c|}{ Bangladesh - 126,606 $(1,621)$} \\
\hline \multicolumn{2}{|c|}{ Indonesia - 50,187 (2,620) } \\
\hline \multicolumn{2}{|c|}{ Nepal - 11,162(26) } \\
\hline \multicolumn{2}{|c|}{ Thailand - 3,158 (58) } \\
\hline \multicolumn{2}{|c|}{ Maldives - 2,260 (8) } \\
\hline \multicolumn{2}{|c|}{ Sri Lanka - 2,010 (11) } \\
\hline \multicolumn{2}{|c|}{ Myanmar - $293(6)$} \\
\hline \multicolumn{2}{|l|}{ Bhutan - $70(0)$} \\
\hline \multicolumn{2}{|c|}{ Timor-Leste - $24(0)$} \\
\hline \multicolumn{2}{|l|}{ DPR Korea - $0(0)$} \\
\hline
\end{tabular}

Sumber :word health organization (WHO

Pada tabel di atas, dari 11 negara terkonfirmasi 668.875 kasus, total kematian sebanyak 19,244. Indonesia merupakan Negara yang memiliki angka kasus dan kematian yang cukup tinggi. Jika dibandingkan dengan Negara Bangladesh, yang jauh lebih tinggi angka kasusnya, tapi angka kematiannya berada di bawah Indonesia. Terkonfirmasi Bangladesh sebanyak 126.606 kasus, angka kematian sebanyak 1.621 jiwa. Ini menunjukkan masyarakat Indonesia masih perlu patuh terhadap peraturan yang telah diterapkan oleh peme-

${ }^{8}$ Ibid rintah. Memperbaiki pola perilaku dalam kehidupan sosial dengan memperhatikan pola hidup sehat dan penerapan physical distancing.

Kedua, Kondisi perekonomian dan rupiah semakin melemah akibat covid-19 yang merupakan salah satu dampak negatif. Sektor industri tidak berjalan efektif sehingga terjadi pemutusan hubungan kerja (PHK) bagi buruh atau pekerja. Hal itu sangat mempengaruhi kondisi perekenomian masyarakat Indonesia. Sebagaimana kita ketahui, bahwa ekonomi merupakan faktor penting dalam keluarga. Ekonomi menjadi lemah sejak adanya pandemi ini, menurut menteri keuangan sri mulyani, bahwa partumbuhan ekonomi bisa tertekan 2,5 persen hingga 0 persen. Hal ini bisa terus terjadi jika pemerintah tidak melakukan strategi pencegahan yang baik. ${ }^{9}$ Pelemahan ekonomi di Indonesia ini bisa berdampak terhadap pertumbuhan ekonomi nasional bahkan global, jika strategi yang dilakukan dengan cara cetak uang maka Indonesia akan mengalami inflasi. Dampak lain dari covid-19 pada sektor ekonomi antara lain, perkerja yang dirumahkan dan pemutusan hubungan kerja (PHK), lebih dari 1,5 juta, dari jumlah ini 90 persen di rumahkan dan 10 persen di PHK. ${ }^{10}$ Angka tersebut, bisa jadi akan bertambah jika Indonesia belum pulih dari penyebaran covid-19, sehingga tenaga kerja yang di rumahkan belum mendapatkan kepastian.

Perputaran ekonomi pada sektor penerbangan, sejak februari sampai dengan mei 2020, mengalami penurunan. Lima bandara utama di Indonesia menagalami peru-

${ }^{9}$ Silpa Hanoatubun, "Dampak Covid-19 Terhadap Perekonomian Indonesia," Journal Education, Psychology And Counseling2 No. 1 (2020). Hlm. 151.

${ }^{10}$ Ibid, Hlm. 151 
bahan yang signifikan, salah satu diantaranya penerbangan domestik bandara soekarno hatta pada bulan Februari sebanyak 1.551 .967 penerbangan, hingga data terakhir di bulan Mei hanya mencapai 27.500 penerbangan. ${ }^{11}$ Hal ini merupakan kepanikan yang terjadi sehingga pemerintah membatalkan beberapa penerbangan, tapi kebijakan ini merupakan langkah awal yang tepat untuk mencegah penyebaran covid19. Beberapa dampak yang ditimbulkan di atas adalah beberapa maskapai melakukan PHK terhadap karyawan atau karyawan dirumahkan, sehingga berpengaruh terhadap angka kemiskinan yang semakin meningkat.

Bukan hanya tenaga kerja di perusahaan resmi yang terkena dampaknya. Tapi hampir semua sektor, baik pedagang kecil di pasar, rumah makan, restoran, karyawan mall, ojek online, transportasi umum, dan lain sebagainya. Perubahan itu dapat mempengaruhi perilaku sosial, seperti angka kejahatan semakin meningkat dengan motif copet di tempat keramaian, pencurian di supermarket, penipuan dalam bentuk online. Berbagai macam kejahatan yang dapat muncul selama adanya wabah covid-19, itu menandakan bahwa perilaku sosial mengalami pergeseran, perubahan itu bukan hanya dilihat dari sisi positif tetapi juga mengalami perubahan pada sisi negatif.

\section{Pengaruh Covid-19 Terhadap Perila- ku Sosial}

Pengaruh covid-19 terhadap lingkungan dan perilaku sosial dapat dilihat de-

\footnotetext{
${ }^{11}$ Badan Pusat Statistik, Jumlah Penumpang Yang Berangkat Pada Penerbangan Domestik Di Bandara Utama Indonesia, 2006-2020 (Orang), 2020.

Https://Www.Bps.Go.Id/Linktabledinamis/View/Id/ 812. Akses 2 Juli 2020.
}

ngan perubahan budaya sehari-hari. Masyarakat dituntut untuk tetap berada pada ketertiban. Karena masyarakat yang hidup dalam Negara hukum, berarti keduanya tidak bisa dipisahkan antara masyarakat dan ketertiban. Dalam hal mewujudkan ketertiban dalam masyarakat, diperlukan sub-sub tatanan, yaitu kebiasaan, hukum, dan kesusilaan. $^{12}$ Perilaku tersebut terbentuk dengan adanya tatanan-tatanan tersebut, ada kebiasaan yang dilakukan secara terus menurus dalam masyarakat, ada hukum yang melandasi sehingga itu sudah menjadi norma yang berlaku, ada kesusilaan, yaitu rasa kemanusiaan terhadap sesama. Begitulan yang mesti berlaku dalam masyarakat dalam menghadapi wabah covid-19. Kebiasaan dalam menjaga diri dan orang lain dalam penyebaran covid-19, mematuhi hukum yang telah ditetapkan oleh pemerintah, serta memiliki rasa tanggung jawab terhadap sesama untuk saling melindungi satu sama lain. Seperti pembahasan selanjutnya, akan dibahas mengenai pola perilaku sosial dalam lingkungan wabah virus covid-19.

\section{a. Konsep Perilaku Sosial Physical Distancing}

Konsep physical distancing telah ditetapkan oleh organisasi kesehatan dunia (WHO).Atas dasar bahwa kehidupan sosial, manusia tetap berhubungan dan berkomunikasi dengan satu sama lain. Oleh karena itu istilah social distancing sengaja diubah menjadi istilah physical distancing, agar hubungan sosial tetap berjalan dengan berbagai cara tanpa berada di dalam ruangan yang sama dengan orang lain secara fisik. Konsep yang akan diterapkan dalam lingkungan sosial di tengah pandemi covid-19 ini telah banyak diterapkan oleh pemerintah dalam bentuk penerapan peraturan perundang-undangan. Pasal 1 ayat (1) Undang-Undang Nomor. 6 Tahun 2018 Tentang Kekarantinaan Kesehatan yang berbunyi,

12 Satjipto Rahardjo, Ilmu Hukum. (Bandung: PT Citra Aditya Bakti, 2012). Hlm. 14 
"kekarantinaan kesehatan adalah upaya mencegah dan menangkal keluar atau masuknya penyakit dan/atau faktor ri-siko kesehatan masyarakat yang berpo-tensi menimbulkan kedaruratan keseha-tan masyarakat". ${ }^{13}$

Dalam hal pembatasan jarak fisik bagi masyarakat, agar tidak terjadi penyebaran penyakit yang dimaksud adalah sebagai upaya untuk menimbulkan kesadaran hukum masyarakat dan kerja sama semua pihak untuk mencegah terjadinya penyebar luasan covid-19 yang dapat mengancam kesehatan dan nyawa orang lain. Kesadaran hukum yang dimaksud adalah kesadaran datang dari diri sendiri tanpa tekanan, paksaan, atau perintah dari luar untuk tunduk pada hukum yang berlaku. ${ }^{14}$ Artinya dengan adanya kebijakan yang telah ditetapkan oleh pemerintah, masyarakat semestinya tidak perlu lagi dipaksa oleh pihak berwajib untuk tunduk pada aturan. Seperti kebijakan menggunakan masker pada saat keluar rumah, itu sudah menjadi kewajiban setiap masyarakat dan sekiranya kebijakan ini sudah tersampaikan keseluruh lapisan masyarakat, apalagi didukung oleh kondisi lingkungan sosial dimana masyarakat sudah banyak yang menerapkan.

Kebijakan lockdown dari pemerintah sebagai upaya untuk mencegah penyebaran covid-19 dari satu wilayah ke wilayah lain. Sejumlah daerah yang terdampak, dan aktivitas masyarakat hampir semuanya di rumahkan atau work from home (WFH). Kebijakan ini dipertimbangkan secara ketat oleh pemerintah dengan mengindentifikasi suatu wilayah dengan mempertimbangkan konsekuensi yang akan ditimbulkan secara matang, baik dari segi

\footnotetext{
${ }^{13}$ Pasal 1 Ayat (1) Undang-Undang Nomor 6 Tahun 2018 Tentang Kekarantinaan Kesehatan

${ }^{14}$ Ellya Rosana, "Kepatuhan Hukum Sebagai Wujud Kesadaran Hukum Masyarakat." Jurnal Tapis10 No. 1 (2014). Hlm. 3
}

ekonomi maupun sosial. ${ }^{15}$ Sebagaimana kita ketahui kebijakan lockdown lebih luas mencakup tentang karantina rumah, karantina rumah sakit, karantina wilayah, pembatasan sosial berskala besar (PSBB). Dengan tujuan bahwa melindungi masyarakat dari penyakit dan atau faktor risiko kesehatan masyarakat, mencegah dan menangkal penyakit demi meningkatkan ketahanan nasional di bidang kesehatan.

\section{b. Perilaku Sosial EraNew Normal}

New normal adalah harapan baru di tengah pandemi covid-19, tetapi tetap ada kekhwatiran di dalamnya berkaitan dengan ancaman kesehatan masyarakat. konsepnew normal ini merupakan strategi pemulihan ekonomi secara nasional. Kebijakan Presiden Republik Indonesia, Joko Widodo dalam bersiap untuk 'new normal' dengan dalil bahwa, "kehidupan kita sudah pasti berubah untuk mengatasi risiko wabah ini, itu keniscayaan. Itulah yang oleh banyak orang disebut sebagai new normal atau tatanan kehidupan baru".

Perubahan sosial (sosial change) terjadi karena dua faktor yaitu pertama, perubahan sosial terjadi karena ada proses perencanaan (planned change) terlebih dahulu baik dari segi waktu, pola biaya, manusia-manusianya, dan lain sebagainya. Kedua, perubahan sosial terjadi tanpa direncanakan terlebih dahulu, artinya perubahan dalam kehidupan sosial terjadi karena disebabkan beberapa hal seperti, adanya penjajahan, bencana alam, dan lain-lain. ${ }^{16}$

Perubahan sosial yang direncanakan merupakan perubahan yang telah diperkirakan terlebih dahulu olah ora-

\footnotetext{
${ }^{15}$ Nur Rohim Yunus AndAnnissa Rezki. "Kebijakan Pemberlakuan Lockdown Sebagai Antisipasi Penyebaran Corona Virus Covid-19". Jurnal Sosial \&Budaya Syar-I, 7 No. 3 (2020). Hlm. 229

${ }^{16}$ Juhaya S. Praja, Teori Hukum Dan Aplikasinya. (Bandung: Cv.Pustaka Setia, 2014). Hlm. 44
} 
ng-orang yang ingin melakukan perubahan dalam masyarakat. pihak yang akan melakukan prubahan disebut sebagai agen of change atau agen perubahan. Terutama yang berperan penting di dalamnya adalah orang yang peduli dan peka terhadap lingkungan sekitar. Di era pandemi ini banyak pihak yang peduli terhadap sesama, sehingga usaha-usaha yang dilakukan agar dapat menghasilkan perubahan dalam masyarakat sosial. individu secara personal maupun individu secara berkelompok yang mempunyai ide baru untuk pengembangan keiatan-kegiatan yang dapat membawah perubahan dalam masyarakat. artinya dalam berperan dalam situasi covid-19, tidak serta merta hanya pihak yang berwajib melakukan kegiatan untuk perubahan sosial tetapi semua pihak memiliki hak dan kewjiban yang sama demi penghidupan yang aman dan damai.

Dengan demikian, cara tersebut di atas sudah menyiapkan suatu cara untuk mempengaruhi masyarakat dengan kosepsi dan sistem yang teratur dan terarah yang disebut sebagai social engineering atau bisa juga disebut dengan istilah social planning. Berkaitan dengan perubahan sosial yang terjadi setlah adanya wabah covid-19, maka perubahan sosial yang diterimah masyarakat, keduanya dapat diterapkan. Yaitu perubahan sosial yang tidak direncanakan (unplanned change), karena perubahan datang secara tiba-tiba menyerang masyarakat Indonesia, sehingga terjadi perubahan, dan perubahan sosial yang direncanakan, cara ini merupakan yang sangat signifikan diterapkan dan pengeruhnya cukup ketat dalam masyarakat.

berbagai kebijakan yang dikeluarkan oleh pemerintah dalam hal mengurangi angka kasus dan penyebaran covid-19 dalam masyarakat. kebijakan itu berupaphysical distancing, anjuran penggunaan APD, pola hidup sehat,
PSBB, pembatasan aktiviatas pelajar dan pegawai. Perubahan itu tentu membutuhkan dukungan dari masyarakat, karena hukum atau kebijakan yang dikeluarka oleh pemerintah untuk masyarakat itu sendiri.Atau dengan istilah,"hukum untuk manusia, bukan manusia untuk hukum"17, menurut sang maestro penggagas hukum progresif Satjipto Rahardjo.

Pola perubahan dapat diakukan dengan berbagai macam ide penemuanpenemuan baru dalam bidang ilmu pengetahuan dan teknologi, yaitu:

1. Discovery, yaitu penemuan unsur kebudayaan yang baru, baik berupa ide ilmu pengetahuan maupun teknologi oleh pihak-pihak perseorangan maupun kelompok;

2. Invention, yaitu apabila penemuan sudah dapat diterimah, diakui, dan diterapkan dalam masyarakat;

3. Diffusion, penyebaran dari temuan-temuan tersebut dapat dilakukan baik secara langsung maupun tidak langsung. 18

Hal tersebut di atas dapat menggambarkan situasi perubahan dalam masyarakat Indonesia saat ini. Di mana perubahan yang terjadi merupakan penemuan budaya baru, secara perlahan diterimah dan diterapkan oleh sebagian besar masyarakat. prsoses pengenalan budaya baru tersebut membutuhkan waktu untuk dikonsepkan. Lalu dilakukan dengan berbagai cara bentuk edukasi dan sosialisasi, baik secara langsung mapun tidak langsung, seperti peran lembaga informasi, baik media internet, $\mathrm{TV}$, maupun alat komunikasi lainnya. Itulah fungsi ilmu pengetahuan

${ }^{17}$ Suteki, Masa Depan Hukum Progresif(Yogyakarta: Penerbit Thafa Media, 2015). Hlm 3

${ }^{18}$ Ibid, Hlm. 46 
dan teknologi di masa pandemi seperti saat ini, yang membantu masyarakat dalam hal mempercepat sistem informasi, bahkan membantu untuk melakukan aktivitas dengan sistem media internet.

Pengamat sosiologi Bustami Rahman, berpandangan bahwa new normal akan terbentuk melalui kebiasaan yang baru yang merupakan hasil dari habitual learning, yang telah dilakukan dalam waktu yang lebih lama, sehingga menjadi habit dan melekat pada sikap dan perilaku individu dalam masyarakat. ${ }^{19}$ konsepnew normal ini sebagai kebijakan pemerintah yang dikeluarkan untuk memulihkan aktivitas, karena kita tidak bisa terkungkung lebih lama dalam kebijakan PSBB. Dampak yang ditimbulkan berbagai macam jika aktivitas tertunda, seperti perekonomian, pemerintahan, pendidikan, sosial dan lain sebagainya. Oleh karena itu new normal ini merupakan pengalihan kondisi yang diterapkan dalam masyarakat, agar menjadi habit setiap individu dalam masyarakat.

New normal ini lebih ketat diterapkan dan dilakukan oleh kalangan pegawai pemerintahan dan swasta. Tetapi bisa saja sebagian masyarakat yang belum bisa beradaptasi dengan lingkungan atau tidak terbiasa dengan pola hidup sehat, seperti cuci tangan, pakai masker ketika keluar rumah, jaga jarak. Artinya tidak turut serta mendukung dan patuh terhadap kebijakan sesuai dengan protokol kesehatan. maka Indonesia akan lebih lama beradaptasi dengan new normal. Karena interaksi sosial dan lingkungan alam akan berjalan dengan baik dan sesuai dengan normanorma yang berlaku, sangat berpengaruh pada suatu kondisi yang aman dan

\footnotetext{
${ }^{19}$ Basuki, "Pengamat Sosiologi Penerapan New Normal Vs Old Normal Terkait Situasi Covid19”, $\quad$ Http://Ubb.Ac.Id/2020/05/27/PengamatSosiologi-Penerapan-New-Normal-Vs-Old-NormalTerkait-Situasi-Covid-19, Akses 2 Juli 2020.
}

kondusif. ${ }^{20}$ Perilaku individu di dalam masyarakat dituntun oleh norma-norma sosial yang menjelaskan apa yang hendak dilakukan dalam berbagai situasi. ${ }^{21}$

Berdasarkan hal di atas, konsep new normal sudah diterapkan, tetapi jika masyarakat kembali pada perilaku awal sebelum covid-19 melanda, dalam artian tidak menjaga kesehatan dan tidak menjaga jarak satu sama lain. Maka bisa jadi penyebaran covid-19 semakin meningkat. dan akan kembali pada kondisi sebelumnya yaitu tenaga kerja kembali di rumahkan. Siklus itu akan terus berputar jika kesadaran masyarakat tidak dibangun sejak awal, dengan mematuhi peraturan sesuai protokol kesehatan. Artinya ada perilaku yang menyimpang dan tidak adanya rasa solidaritas masyarakat dalam pencegahan penyebaran covid-19. Dalam teori Durkheim yang klasik dalam penelitian hukum di dalam masyarakat, berkaitan dengan fenomena solidaritas sosial yang terdapat di antara anggota masyarakat. ${ }^{22}$

Solidaritas sosial itu belum membentuk masyarakat, dimana hubungan anggota masyarakat antara satu dengan lain dalam lingkungan kehidupan hanya bersifat kadangkala. Meskipun solidaritas sosial tidak dapat diukur secara pasti tapi setidaknya dapat diamati. Solidaritas sosial yang dimaksud adalah kaitannya dengan perilaku sosial dalam memerangi covid-19, yaitu untuk saling mendukung satu sama lain. Saling pengertian, mengedepankan kepentingan bersama dibandingkan kepentingan individu. Dalam hal solidaritas masyarakat memerangi covid-19

${ }^{20}$ Bakhtiar, "Hukum Dan Pengendalian Perilaku Masyarakat." Jurnal Al-Qalb9 No. 2 (2017). Hlm. 175.

${ }^{21}$ Samsir Salam, "Hukum Dan Perubahan Sosial (Kajian Sosiologi Hukum)," Tahkim 11 No. 1 (2015). Hlm. 161.

${ }^{22}$ Satjipto Rahardjo, Hukum Dan Masyarakat(Bandung: Penerbit Angkasa Bandung, 1980). Hlm. 103 
dengan saling mendukung satu sama lain untuk mematuhi kebijakan pemerintah yang telah dikeluarkan. Solidaritas ini yang semestinya harus diterapkan dalam pola perilaku kehidupan new normaluntuk membentuk keharmonisan dalam kehidupan bersama.

\section{F. Kesimpulan}

Covid-19 merupakan penyakit menular yang sangat mengancam nyawa manusia. oleh karena itu, perilaku physical distancing sangat berpengaruh terhadap pemutusan mata rantai penyebaran covid19. Masyarakat tidak bisa menyepelekan hal tersebut karena covid-19 akan menimbulkan dampak negatifyang sangat luas, mulai dari korban jiwa, pelemahan di sektor ekonomi, pendidikan dan industri. Di sisi lain, dampak positif yang ditimbulkan adalah pengurangan emisi dan peningkatan kualitas udara selama covid-19 melanda Indonesia. Oleh karena itu, pola perilaku manusia dalam memerangi covid-19 sangat penting. Peningkatan penyebaran penyakit menular ini tergantung pada masyarakat dalam berperilaku terhadap lingkungan sosial. masyarakat dituntut berperan sebagai agen perubahan (agen of change), yang dilakukan melalui tahap perencanaan (planned change).

Meskipun telah diterapkan konsep new normal di beberapa daerah, tetapi perilaku sosial tetap harus mendukung dengan saling menjaga kesehatan satu sama lain. Serta mengindahkan kebijakan pemerintah, mengurangi aktivitas di luar rumah jika tidak penting. New normal tidak sematamata masyarakat bebas beraktivitaas seperti sedia kala, tetapi tetap memperhatikan peraturan yang telah dikeluarkan oleh pemerintah.

kondisi lingkungan sosial akan pulih ketika masyarakat dalam memerangi covid19 mengedepankan solidaritas. Covid-19 menganjurkan jaga jarak fisik bukan berarti mengajarkan kita hidup ditengah masyarakat dengan mengedepankan sikap individuallistik. Justru rasa peduli sesama, mengharuskan kita untuk saling membatasi diri. Itulah fungsi media komunikasi dan informasi yang tidak mengharuskan masyarakat bertemu secara langsung untuk mengaksesnya.

\section{DAFTAR PUSTAKA}

\section{Buku}

Antonius Atosokhi Gea, and Antonina Panca Yuni Wulandari. Relasi Dengan Dunia. Jakarta: PT Elex Media Komputindo, 2013.

Juhaya S. Praja, Teori Hukum Dan Aplikasinya. Bandung: Cv.Pustaka Setia, 2014.

Satjipto Rahardjo.Hukum Dan Masyaarakat. Bandung: Penerbit Angkasa, 1980. ilmu hukum. Bandung: PT Citra Aditya Bakti, 2012.

Suteki, Galang Taufani. Metodologi Penelitian Hukum (Filsafat, Teori Dan Praktik). Depok: Rajawali Pers, 2018.

—. Masa Depan Hukum Progresif. Yogyakrta: Penerbit Thafa Media, 2015

Zainuddin Ali. Metode Penelitian Hukum. Jakarta: Sinar Grafika, 2016.

\section{Artikel Jurnal}

Adityo Susilo, dkk. (2020) "Coronavirus Disease 2019: Tinjauan Literatur Terkini." Jurnal Penyakit Dalam Indonesia 7 no. 1 (2020).

Bakhtiar. "Hukum dan Pengendalian Perilaku Masyarakat." Jurnal Al-Qalb 9 no. 2 (2017)

Ellya Rosana."Kepatuhan Hukum Sebagai Wujud Kesadaran Hukum Masyarakat." Jurnal Tapis10 no. 1 (2014).

Nur Rohim Yunus, Annissa Rezki. (2020) "Kebijakan Pemberlakuan Lockdown Sebagai Antisipasi Penyebaran Corona Virus Covid-19", Jurnal Sosial \& 
Budaya Syar-I 7no.3 (2020).

Samsir Salam. "Hukum Dan Perubahan Sosial (Kajian Sosiologi Hukum)." Tahkim 11 no. 1 (2015)

Silpa Hanoatubun, dkk."Dampak Covid - 19 Terhadap Perekonomian Indonesia."Journal Education, Psychology And Counseling 2 no.2 (2020)

\section{Peraturan Perundang-undangan}

Undang-Undang Nomor. 6 Tahun 2018 Tentang Kekarantinaan Kesehatan

Undang-Undang Nomor 32 Tahun 2009 Tentang Pengelolaan Dan Perlindungan Lingkungan Hidup

Peraturan Pemerintah Nomor 21 Tahun 2020 Tentang Pembatasan Sosial Berskala Besar (PSBB).

Peraturan Menteri Kesehatan Nomor 9 Tahun 2020 Tentang Pedoman Pembatasan Sosial Berskala Besar Dalam Rangka Percepatan Penanganan Corona Virus Disease 2019 (Covid-19).

\section{Media Online}

Badan Pusat Statistik. "Jumlah Penumpang Yang Berangkat Pada Penerbangan Domestic Di Bandara Utama Indonesia, 2006-2020 (Orang)”. 2020 https://www.bps.go.id/linkTableDinamis/view/id/812.

Basuki. (2020). "Pengamat Sosiologi Penerapan New Normal Vs Old Normal Terkait Situasi Covid-19." 2020 http://ubb.ac.id/2020/05/27/pengamat-sosiologipenerapan-new-normal-vs-old-normal-terkait-situasi-covid-19.

Henriques, M. "Virus Coron: Dampak 'Lockdown' Pada Pemurunan Polusi Akankah Selamanya?.” 2020 https://www.bbc.com/indonesia/vert-fut-52194438. diakses 4 Juni 2020.

Prabandari, A.I."Pandemi Covid-19 Kurangi Polusi Udara Sejumlah Negara, Begini Keadaan Indonesia.” 2020 https://www.merdeka.com/jateng/pandemi-covid19-kurangi-polusi-udara sejumlah-negera-ini-fakta-yang-terjadi-di-indokln.html.

WHO. "WHO Supports Countries To Mitigate Covid-19 Spread In The Region." 2020 https://www.who.int/southeastasia/outbreaks-and emergencies/novelcoronavirus-2019. 